\title{
Russian-Slovak Contacts: From Alexander I until the Last Quarter of the Nineteenth Century
}

\author{
Galina V. Rokina
}

Mari State University, Yoshkar-Ola, Russia

Email: galina@rokina.ru

Miroslav Daniš

Alexander V. Randin

Comenius University, Bratislava, Slovakia

\section{Doi:10.5901/mjss.2015.v6n3s7p149}

\section{Abstract}

The article deals with the most significant cases of Russian-Slovak cultural and scholarly connections in the nineteenth century, starting from the first mentions of inclusion of Slavs into the programs of Decembrists to 1870s when Slovaks came to study at Russian universities. The researchers' attentions is concentrated mostly on the perception of Slovaks in Russia and their image in the Russian society. First, the researchers identified the basic stages in the development of Russian-Slovak contacts and the ways of collaboration of Russian and Slovak intellectuals. Then they analyzed the political situation that greatly influenced the intensity of the Russian-Slovak contacts in the various stages of the time span from the years of Alexander I rule to the last quarter of the nineteenth century. A prominent place in the article is dedicated to the role of M.F. Raevskii, archpriest of the Orthodox church of the embassy of the Russian empire in Vienna, adherent to the idea of Slavic mutuality. The first complete publication of the Slavic correspondents of M.F. Raevskii was issued in 2014 in Bratislava.

Keywords: Russian-Slovak contacts, slavic mutuality, Hungarians slavs, magyarization, russian and slovak intellectuals, Alexander I, M.F. Raevskii, S.Hurban-Vajansky, Slavic question.

\section{Introduction}

Interrelations of peoples and linguistically and ethnically close peoples, have always been in the center of research interests. Russian - Slovak connections and their reciprocal influence still remain the subject of study of a narrow circle of specialists in spite of growing importance of this problem.

At the beginning of 2000s, the Slovak association of Russian studies published a collection of papers devoted to the problems of Slovak-Russian connections (Slovensko-ruske vztahy a suvislosti, 2002). Helena A. Pravda, a Russian teacher of Constantin the Philosopher University published the results of her experimental study entitled "How do contemporary Slovaks perceive Russians?" (Slovensko-ruske vztahy a suvislosti, 2002). Among the conclusions of this work there was a thesis that the popularity of Russians and Russia in Slovakia is quite low and keeps going down. In her opinion, negative stereotypes in the attitude to Russians prevail today. No doubt, political situation and international relations have paid their token to such an attitude. It would probably not be a mistake to affirm that today, fifteen years after, the results of this research could be similar, if not worse.

In this connection, the analysis of Russian-Slovak contacts in the historical perspective becomes a matter of particular importance for the study of the formation and transformation of stereotypes in the history of Russian-Slovak collaboration.

\section{Method}

The research is based on a number of published and unpublished sources. In particular, we use the memoirs of contemporaries, actors of the Russian-Slovak contacts. These are mostly archival materials from the funds of the Ministry of Education (ministerstvo narodnogo obrazovaniia) of the Russian empire and the Department of General Affairs (department obshchikh del) of the Ministry of the Interior from the Russian State Historical Archives (RGIA), some files 
from personal funds (V. Lamanskii) of the St. Petersburg branch of the archives of the Russian Academy of Sciences.

Raevskii's archive, published thanks to the work of a Slovak researcher V. Matula with collaboration of one of the authors of this article Miroslav Daniš (Matula B. (1975); Daniš M. - Matula V. (2014) has been especially useful for our research. The last publication of Raevskii's archive holds more than 300 letters from his Slovak correspondents. M.F. Raevskii worked as an archpriest at the Orthodox Church at the Russian embassy in Vienna from 1842 to 1884.

\section{Results}

The first programs of inclusion of Slovaks into the Russian political plans can be found in the programs of the Decembrists. As is known, Decembrists worked out a plan of creation of federative units and nation states in the Balkans. It is in the 'Southern Society' (Iuzhnoe obshchestvo) and the 'Society of the United Slavs'(Obshchestvo soedinennykh slavian) that the first projects of Balkan and Slavic federations appeared. Academician M.V. Nechkina maintains that the members of the 'Society of the United Slavs' considered Hungarians Slavs as well. Taking into the account the often mistaken view that time when Slovaks were called Slavs, we believe that the members of the society simply followed this pattern ( Rokina, 2005).

Writing about Slovaks as Hungarians is not uncommon for the Russian press of the 1910s-1920s. Only in 1830s1840s, when Russian scientists and scholars established connections with Slavic public figures, this mistake was corrected. Russian society learned to distinguish between Slovaks (or 'Slovenians', as we would often find in the literature) and Bohemians and Hungarians.

An important role in the changing perception of Slovaks as a part of a common Slavic tribe was played by the trips of Russian scientists and intellectuals to the Slavic lands in 1830s-1840s. Getting to know the real life of the Western Slavs, their history, language and literature and leading representatives of the Slavic intelligentsia made the first Russian Slavophils look at the Slavic world under a different angle. On the other hand, there are grounds to believe that the new view of Europe through the 'Slavic prism' led to the strengthening of the contrasts between the Slavic and RomanGerman worlds. When Russian scientists and travellers saw how different the living conditions of the Czechs and Slovaks in the Austrian empire and the attitude to Russians were, they often came to a conclusion of a special affection of Slovaks to Russians. This idea was often supported in the speeches of the leaders of the Slovak national movement in which they recognized a special mission of Russia and requested support of the movement. Trips and meetings of the Russian scholars Pogodin, Sreznevskii and Preis with J.Kollár, P.J.Šafarik and L.Štúr are well studied and much is written about them. There is no doubt that precisely after these trips Russian government began to systematically help the leaders of the Slovak movement ( Note 1). The image of the Slovaks in the Russian public opinion also underwent changes. The image was formed by means of the press and public lectures of the University professors. They were no longer mixed with Hungarians, their particular affection to Russians was often mentioned and they were generally considered loyal allies in the Austrian empire (Rokina, 1998).

A Russian historian A.A. Kochubinskii wrote about this time several years after

The epoch of the last half a century is the time of Nicholas I and Alexander II. These are two policies in the Slavic question, policies different in their ends and their results. On the borderline of these two policies there is one memorable event-Sevastopol (Kochubinskii, 1881).

He calls Austrian Slavs 'intimate advocates of our policy' of the time of Nicholas I. If we remember how difficult it was for the Russian scholars to support their Slovak colleagues in the first half of the nineteenth century, secretly 'like the Englishmen gave gunpowder to the Cherkess', it is difficult to ignore the words of A.A. Kochubinskii. He evaluates the Slavic policy of Russia during the preceding period as pro-Austrian and quotes a letter from a serb, Dalmatian poet Tomašič to a Russian Slavist V. Grigorovich. The letter provides a vivid specification of the Slavic policy of the Russian empire of the first half of the nineteenth century.

Travelling in the ...Slavic lands, do not believe good attitudes that a Russian name may produce in some places. In fact, these is the feeling of quite rightful brotherhood; I hope, time will make it more and more lively; but this as only an unhappy state of some unhappy people or, better, some unhappy persons, that make them desire something that they would never reach and that would become to them the last of their misfortunes (Kochubinskii, 1881).

This was Tomašič's idea of Slavic mutuality. Without such examples of Slavic pessimism ( this was also the view of a Czech K.Havliček-Borovsky) all the facts of Slovak favorable attitude towards the idea of Slavic mutuality would have been quite one-sided.

In the 1850s-1860s Russian-Slovak contacts acquired systematic and pragmatic character, first of all for the representatives of Slavophil and Pan-Slavic movements of the Russian social ideas. However, for the majority of the Russian society Slovaks remained almost unknown. This stage in the development of the Russian-Slovak relations was 
preceded by an important event in the history of the Slavic movements - an all-Slav congress of 1867 in Moscow. It was also a turning point in the Russian-Austrian relations. Chronologically the congress took place almost at the same time with the ratification of Austro-Hungarian agreement. Slavic deputies took an active part in this event (almost $80 \%$ of the participants were Austrian Slavs). It actually draw the line under the pro-Russian course of Vienna and the attempts to reconstruct the alliance. For Russia it also became the demonstration of the new political program of 'All-Slav metropoly'.

The congress was organized on the initiative of the Russian scholar in the field of the Slavic studies V. Lamanskii. It was to become a part of ethnographic exhibition that was being prepared in Moscow at that time. M. Raevskii took part in the preparation of the delegation of Austrian Slavs. Matica Slovenska helped to prepare and deliver the exhibits. The representatives of the Slovak delegations in Moscow and St. Petersburg were A.Radlinsky, J.Baltazar, Esensky, Gašpar, P.Mudroň (Kodajová,1999). In the press the participation of the Slavs in the exhibition was described as 'the Slavic way to Moscow'. Hungarian press accused the delegation of Slovaks in the 'demonstration of Pan-Slavism'. Esensky, who had a position of a civil servant, was dismissed for the participation in the congress.

The greatest publicity was given to the initiatives of A.Radlinsky, who called for confessional and linguistic unification of the Slavs both in Moscow and St. Petersburg (Hlavač, 1994). Slovak delegates wrote their impressions about their participation in the congress in the numerous articles in which they also called for Slavic collaboration.

In the Slovak historiography the subject of participation of the Slovaks in the congress of 1867 was greatly influenced by the social situation. Contemporary evaluations are quite similar to the publications in the Slovak magazine Prúdy from the period of the first Czechoslovak republic.

The subject of emigration of Slovaks to Russia is a no less discussed topic, phenomenon that became especially popular before and after the congress in Moscow. Like the Slovak delegation, the departure of the Slovak young people and teachers in 1860s-1880s was assisted by M.F. Raevskii (Daniš, 2014).

The shortage of sources explains little attention that was given to the problem of emigration of Slovak intellectuals to Russia in both Russian and Western historiography. In Czechoslovak historiography of 1960s there was a point of view that till the 'time of S.Hurban-Vajansky', that is, till 1880s, there were no Slovak young people in Russian educational institutions (Mráz, 1964). In Russia this problem was first addressed by S.O.Vialova who published some archival materials from the department of handwritten materials of the public library of St.Petersburg (Vialova, 1968). The concept of emigration of Slovaks to Russia in the Slovak historiography was introduced by V. Matula (Matula, 1975). The Slovak scholar claimed that in the years 1860-70s it was possible to talk about a phenomenon of emigration of Slovak intellectuals to Russia. His evaluation of Slovaks' trips to Russia had a lot of opponents and, first of all, among Slovak historians (Kodajova, 1990). First of all, the discussion started among their contemporaries. Various groups of Slovak intelligentsia discussed this problem on the pages of Slovenske Noviny, Cirkevné listy and Peštbudinske listy.

Russian-Slovak economic contacts have been known since the eighteenth century. These were trade contacts in the borderland areas of the Austrian and Russian empires. In the opinion of a Czechoslovak historian J. Hrozienčik, the trading traditions of Slovak handicraftsmen from Turoč date back to the end of the eighteenth century. (Hrozienčik, 1981). It was these sellers of herbs who may be credited for spreading the so called popular Russophilia in the Slovak society. Petty trade of Slovak handicraftsmen in Russia is often referred to as economic emigration in the literature.

Later some researchers, namely D. Kodajová, speaking about economic emigration of Slovaks to Russia, noted its insignificant character, especially compared to other countries (Kodajová, 1990). According to the data provided by this author, 50385 Czechs and Slovaks lived in Russia in 1897. At the same time, there lived ten times more Slovaks in the USA, Canada, Belgium and Southern Slavic lands.

Economic emigration of Slovaks to Russia came first of all from the Eastern region - Turoč, an area with a long tradition of 'popular Russophilia' which was not connected to the activities of Slovak nationalists but caused by long-term economic connections between this area and Russia. However, it was in Turcansky sv. Martin that a political Russophile movement appeared that later got the name of Martin. S. Hurban-Vajansky was one of its representatives. Most of the Slovak young people went to study to Russia from this area.

In the history of trade of Slovak handicraftsmen in Russia there were several stages when this trade was interrupted by embargo of Russian authorities or, on the contrary, became more intense when the conditions for Slavic settlers in the Southern Russian areas became more favorable. These favorable conditions of the last third of the nineteenth century boosted up the activities of Slovak olejkary (oil sellers), drotary ( handicraftsmen), šafraniky ( saffron sellers). They took part in the season trade in Russia, they would sometimes move as far as the Urals, and some of them settled down and started their own business. According to archival sources, many Slovaks, trading in Russia, requested Russian citizenship from the government ( Note 2).

At the end of 1880s almost in every family of the Turčansky area somebody traded with Russia. As is correctly argued by another Slovak historian R.Tibensky, there was no mass emigration into Russia as was the case in the USA, 
for example (Tibenský, 1986). Still, in the nineteenth century many Slovaks, especially in the summer went to Russia as season workers or traders. They would bind books, make troughs, sell herbs and cloths, etc. Many of them started as petty traders and later became prominent businessmen. In this respect it is worth mentioning the case of the Orsag family, with its best known member J.Miloslav Orsag (1882-1939), a businessman, a member of the delegation of Czechoslovak league, that was received by Nicholas II in September 1914 (Sbornik rozpominok ruských legionarov slovákov, 1933; M. Daniš, 2006).

We are first of all interested in the causes, limits and forms of emigration of Slovak intellectuals to Russia, and also outcomes for both sides. As it is demonstrated by the analysis of publications on the subject (S.O. Vialova, V. Matula) and archival sources, it is possible to speak about considerably high emigration of Slovak young people to Russian educational institutions. The reasons for its beginning were the results of formation of dual Austro-Hungarian monarchy, which worsened the pressure on the Slovaks; a great role was also played by Russophile and Slavophile orientation of Slovak intelligentsia at this time. Quite an important role was also played by the school reform in Russia in 1864 in the Ministry of Public education D.A. Tolstoi. This reform increased the number of hours dedicated to the teaching of ancient languages in the secondary schools. At this time teachers of Greek and Latin were invited to Russia in order to renew the traditions of classical schools in Russian gymnasia.

In 1866 a Slavic teachers' institute was founded in St. Petersburg which lasted for sixteen years (Uchitel'skii institute slavianskikh stipendiatov). First, it trained teachers for the Kingdom of Poland, this is why its students were mainly non-Catholics. At the same time Slovak students started to study in this Institute.

We know at least 28 Slovak teachers and professors, doctors, publicists who came to work in Russia. Among them there was a professor of Banska-Bystritsky Catholic gymnasium Černy (in 1867 this institution was closed in the period of strengthening of Magyarization). Together with his wife and three daughters he came to Moscow where he worked at gymnasium number three for 33 years as a teacher of Latin and Greek. In 1912 he published a 600-page schoolbook 'A new system of Russian stenography'(Sbornik rozpominok ruských legionarov slovákov, 1933).

In the second half of 1860s-1870s Raevskii took an active part in the recruitment of teachers of classic languages from Austrian Slavs for the Ministry of Public Education. In Raevskii's archive (Matula, 1975) there are numerous reports to the Ministry on this subject. This is why Raevskii had all reasons to believe that this action would facilitate rapprochement between Russians and Slovaks. Among Slovaks who went to work in Russia as teachers were teachers E.Černy, J.Stovik and L.Mečatek, historian J.Hložansky. Unlike Czech publicist K.Havliček-Borovsky, who was disappointed by his trip to Russia (Žáček V., 1947), Slovak intellectuals were in raptures over Russian reality and assisted in extending Russo-Slovak connections (Ivantyšynova, 1987). In 1844 K.Havliček wrote from Moscow:

I do not want anything to do with Poles and Russians...Russians and Poles are not our brethren as we call them....Ah if only Kollar could come to Russia instead of me he would be sorry for what he called the Slavs to (Žáček V., 1947).

The fact that Russian authorities allowed Slovak young people to receive education in the Russian educational institutions was, on the one hand, a means of strengthening cultural connections and on the other, it reflected the policy of the government which supported the Slavic movement in the Austro-Hungarian empire.

Strengthening of Magyarization in 1860s did not allow the students who were not Hungarians to finish secondary school (with a few exceptions) and, most importantly, to receive higher education in their country. This is why they were eager to go to study somewhere outside the Kingdom of Hungary. Slovaks were the first to bear these consequences. Slovak students could be seen in many universities of the European countries: Vienna, Leipzig, St. Petersburg, Moscow, etc. They were especially numerous in Prague. Charles University and Czech gymnasia became alma mater to the majority of Slovak intelligentsia.

As archival materials demonstrate, at the beginning of 1866 Moscow and St. Petersburg Universities established special scholarships for 'the young people of Russian descent from Galicia and Hungary, and also Slovaks, preferably Protestants (up to twenty people) who graduated from foreign Universities' (Note 3).

These students could follow the courses 'held by the chairs of the Russian language and literature, Russian history, Slavic philology and the history of the Russian law' (Bokes Fr. , 1956), and could later count on a position of a teacher at a secondary school. This regulation was not widespread because of the complications with the Slavic question. N.A. Miliutin wrote to a trustee of the Warsaw district F.F. Witte 'His Highness does not wish this regulation to be widely known in order not to spread wrong ideas' (Note 3).

By the time the regulation arrived, F.F. Witte had two eligible candidates for these scholarships and one of them was 'Krivoš, a Slovak, Protestant, student of Vienna and Leipzig Universities' (Note 3). These students got scholarships from the Asian Department of the Ministry of Foreign Affairs and mainly from donations collected by the Russian community through charity societies and committees. 


\section{Conclusion}

Taking into consideration the fact that the Slovaks were the subjects of the Kingdom of Hungary that made part of AustroHungarian empire, there were no grounds to speak about political Russian-Slovak contacts. Officially all the RussianSlovak contacts took place in the spheres of scholarly and cultural collaboration of intellectuals of that time. The idea of Slavic mutuality itself in the middle of the nineteenth century existed only for a considerably small circle of scholars of Slavic studies. Starting from 1870s this idea becomes more and more politicized and becomes part of a more complex Slavic question of the foreign policy of the Russian empire (Rokina, 2014).

The main traits of the Slovak stereotype that existed in the Russian literature of the nineteenth century were the following: a people with 'a heart of a pigeon', truly dedicated to the idea of Slavic mutuality, respecting Russians, oppressed by Hungarians and subject to mortal dangers for their loyalty to all things Russian. This stereotype is still used by many authors who are interested in the history and culture of the Slovak people. The political and economic issues that influenced the character and intensity of the Russian-Slovak contacts remain beyond the authors' interests.

\section{References}

Bokes, Fr. (1956). Slovenské školstvo a česko-slovenská vzájomnost v rokoch 1848-1918. 0 vzájomnych vztyahoch čechov a slovákov. 209-210.

Daniš, M.-Matula (2014). V. M.F.Rajevskij a slovaci v 19.storoci. Bratislava. In Acta Historica Posoniensia (XXIII)..

Daniš, M. (2006). Slovaki i Rossiia. Politicheskie kontseptsii i plany v 1900-1917. Russkii sbornik, Vol.3 38-108

Daniš, M. (2014). Ruská politika a Slovania v koncepcii M.F.Rajevského. In Ruská politika na euroázijskom kontinente v moderných dejinách. Acta historica Posoniensia XXV, 7-15;

Hlavač, A. (1994). Slovenská put do Ruska. In Andrej Radlinsky. Spolok sv. Vojtecha. 115-117.

Hrozienčik, J. (1991). Turčianske olejkári a šafránici.

Ivantyšynova, T. (1987). Česi a Slováci videologii ruských slavianofilov.

Kochubinskii, A.A. "Nashi dve politiki v slavianskom voprose". In Istoricheskii vestnik (No place, 1881), 201.

Kodajová, D. (1990). Dobyli ruský trh a školy. In Priroda a spoločnost' 11. 20-25.

Kodajová, D. (1999). Slováci na slovanských zjazdoch -sny, realita a sklamania slovenského rojčenia. In Stredoeurópske národy na križovatkách novodobých dejín 1848-1918. 87-97.

Matula, V.(1971). Emigrácia slovenských intelektuálov do Ruska v 60.-70. rokoch XIX stor. In Zborník Filozofickej fakulty Univerzity Komenského. Historica. Roč. 22., 103-114.

Matula,V. (1975). Zarubezhnye slaviane i Rossiia. Moscow: Nauka.

Mráz, A. (1964). Vpliv ruských ideových prúdov na vývin slovenského myšlenia a literatúry v druhej polovici XIX storočia. In Acta Universitatis Carolinae. Philozophica et historica 3. Universita Karlova, Praha. 40.

Rokina, G.V. (2005). Teoriia i praktika slavianskoi vzaimnosti v istorii slovatsko-russkikh sviazei deviatnadtsatogo veka. Kazan: Izdatel'stvo Kazanskogo universiteta.

Rokina G.V. (2014). Slavianskii vopros v obshchestvennoi mysli i politike Rossii pervoi poloviny deviatnadtsatogo veka. In Ruská politika na euroázijskom kontinente v moderných dejinách. Acta historica Posoniensia XXV. Bratislava, 15-20.

Tibenský, R. (1986). Hlboké korene bratstva // Práca.

Vialova, S.O. (1968). K voprosu o pervykh slovatskikh studentakh v peterburgskom universitete. In Vestnik Leningradskogo universiteta 2. $140-143$.

Žáček, V. (1947). Čeche a polaci roku 1848: Stúdie k novodobym politickym stykům česko-polskym. Praha, 293-294.

\section{Notes}

1. Russian State Historical Archives (RGIA), fund of the Ministry of Public Education.

2. RGIA F. 1284 (Fund of the Department of General Affairs of the Ministry of Internal Affairs).

3. Miliutin N.A. "Pis'mo konfidentsial'noe F.F. Witte ot 11 (23) fevralia 1866 (kopiia)"

St. Petersburg branch of the Russian Academy of Sciences. F. 35, op. 3, e.x. 53, I. 70, 70 ob. 
